\title{
CORRIGENDUM
}

\section{Climate and human influences on global biomass burning over the past two millennia}

J. R. Marlon, P. J. Bartlein, C. Carcaillet, D. G. Gavin, S. P. Harrison, P. E. Higuera, F. Joos, M. J. Power and I. C. Prentice

Nature Geoscience 1, 697-702; published online: 21 September 2008; corrected after print: 23 February 2009.

In this Article, the $y$ axis label of Fig. $4 \mathrm{~d}$ was incorrect; it should have read 'Population $\left(10^{6}\right)$ '. This has been corrected in the HTML and PDF versions. 